\title{
THE MILITARY ROLE OF THE REHOBOTH BASTERS DURING THE SOUTH AFRICAN INVASION OF GERMAN SOUTH WEST AFRICA, 1914-1915
}

\author{
G.J.J. OOSTHUIZEN \\ Department of History, Potchefstroom University for $\mathrm{CHE}$
}

\section{SUMMARY}

During the course of the South African invasion (1914/15) and their forced involvement in the German war effort caused great consternation among the Rehoboth Basters. They feared that should they actively support the Germans, they could lose their land and their right to selfdetermination. Accordingly, Captain Cornelius van Wyk visited General Louis Botha in Swakopmund in April 1915. Botha advised them to avoid becoming involved in the war effort as far as possible. The Basters, however, in spite of Botha's advice, rebelled against the Germans. The timely arrival of the South African forces in the Rehoboth Gebiet and the resultant withdrawal of the Germans to the north prevented the Germans from delivering the final blow to the Basters. With the Peace of Khorab (9 July 1915) the German administration in South West Africa was formally ended.

Gedurende die Suid-Afrikaanse inval (1914/15) het die noodgedwonge betrokkenheid van die Rehoboth-Basters by die Duitse oorlogspoging groot ontsteltenis in Bastergeledere veroorsaak. Die Basters was bevrees dat indien hulle die Duitsers aktief sou steun, hulle moontlik hulle grondgebied en reg tot selfbestuur kon verloor. Gevolglik het kaptein Cornelius van Wyk generaal Louis Botha in April 1915 te Swakopmund besoek. Laasgenoemde het hulle aangeraai om sover moontlik nie by die oorlog betrokke te raak nie. Die Basters het egter ondanks die advies van Botha teen die Duitsers in opstand gekom. Die tydige aankoms van die Suid-Afrikaanse magte in die Rehoboth-Gebiet 
het die gevolglike onttrekking van die Duitsers na die noorde, het verhoed dat die Duitsers die Basters die finale nekslag toedien. Met die Vrede van Khorab (9 Julie 1915) is die Duitse administrasie in Suidwes-Afrika formeel beëindig.

\section{INTRODUCTION}

A group of people of mixed descent, who had their origin in the eighteenth century in the North-Western Cape, and who later became known as the Rehoboth Basters, left the Cape Colony in 1868 and settled in Rehoboth and vicinity in the area which would later become known as German South West Africa. Their pre-colonial settlement (1868-1884) was characterised by fruitless attempts to acquire the Rehoboth Gebiet ' as permanent residential area and to maintain neutrality amidst the HereroNama-Oorlam conflict.

The establishment of German authority in South West Africa was consequently seized by the Rehoboth Basters to safeguard their own position. In September 1885 the so-called Friendship and Protection Treaty between the Basters and Germans was concluded. Although this treaty, to a great extent, confirmed the previously acquired freedom and rights of the Basters, the independent executive powers of the captain and Baster Council, especially with regard to "foreign policy", were significantly curtailed. In due course the Rehoboth Basters were increasingly involved in the German effort to subject the indigenous inhabitants. After the signing of the military treaty of 26 July 1895, the Basters were trained as soldiers and conscripted to do military service. Although the Rehoboth Basters undoubtedly enjoyed more privileges than the other local population groups during the German administration period, other aspects of their privileged position were also gradually curtailed. This was done, despite the 1885 agreement and continuous loyalty such as was, among others, proven in practice by the rendering of valuable military assistance. In this regard it was especially taxability, the gradual implementation of German laws, the abolition of the position of the captain and the impairment of the independent executive powers of

The word Gebiet-(territory) dates from the German government's rule and was retained during the South African administration. 
the Baster Council, that caused dissatisfaction. In addition, the management of boundary and land issues also drove a wedge into the initial friendly Baster-German relations. ${ }^{2}$

\section{REINSTATEMENT OF THE BASTER CORPS}

The First World War which broke out in August 1914, was a dramatic event with far-reaching consequences for South Africa and South West Africa. At the request of Great Britain, the South African Government decided to occupy the harbours of Swakopmund and Lüderitzbucht and to neutralise several radio stations in the area. ${ }^{3}$ This decision caused violent opposition in South Africa itself and led to the outbreak of the Rebellion. As a result the invasion was delayed for some time. ${ }^{4}$ This gave the German rulers in German South West Africa the opportunity to make final military arrangements.

Aware of his own limited means of defence, ${ }^{5}$ and obviously wellinformed regarding the military force that South Africa could muster against him, ${ }^{6}$ Governor Dr. T. Seitz and the military commander, Lieutenant Colonel Von Heydebreck, concentrated on keeping the South African invading forces occupied as long as possible, hoping for a German victory in Europe. To achieve this objective, they decided to conscript also non-German citizens for military service. ${ }^{7}$ This resulted in the Basters openly opposing the German government.

Based on the order of the commander of the Schutztruppe (protection troops) that all able-bodied Baster men were to be called up, Captain Baron Hiller von Gaertringen, the German Bezirksamtmann (magistrate) of Rehoboth, arranged a meeting with the Baster Council

2 G.J.J. Oosthuizen, Die Rehoboth-Basters binne die konteks van die staatkundige verhoudinge tussen Suidwes-Afrika en Suid-Afrika, 1915-1939 (Ph.D., PU for CHE, 1993), p.313.

3 G-M. Cockram, South West African Mandate (Cape Town, 1976), pp.13,15; Archives of the South African Defence Force (SANDF), Unie van Zuid-Afrika. Departement van Verdediging, Rapport voor het jaar geëindigd 30 Junie 1921, pp.6-7.

4 T.R.H. Davenport, South Africa. A modern history (Bergvlei, 1988), pp.271-272.

5 The Germans could scarcely muster a force of 5000 troops. Cf. E.L.P. Stals, Die rol van Viktor Franke in Suidwes-Afrika 1896-1915 (Johannesburg, 1972), pp.63,65.

6 In March 1915, South Africa had 43402 soldiers and at the end of the campaign South Africa had 67237 soldiers in the field. Cf. Public Record Office, London (PRO) CO 551:129, a Historical Record of the Campaign in German South West Africa, ca. October 1920, p.55; SANDF Unie van Zuid-Afrika. Departement van Verdediging, Rapport voor het jaar geëindig 30 Junie 1921, p.7.

7 P. Pearson, The history and social structure of the Rehoboth Baster community of Namibia (MA dissertation, University of the Witwatersrand, 1986), p.156. 
early in August $1914 .^{8}$ His request to assist the Germans in the protection of German South West Africa was met with fierce opposition. The council members appealed to the military treaty of 26 July 1895 and pointed out that it only applied to indigenous wars and besides that, it had in the meantime lapsed. They furthermore alleged that barely fifty members of the old Baster Corps were able to perform military service and that their children had undergone no military training. ${ }^{9}$ Lastly, the Basters did not wish to become involved, because it was a conflict between whites. $^{10}$

A Baster delegation consequently visited Governor Seitz with the request that they remain neutral. Seitz, however, assured them that it was a conflict between whites and that they would only be used for police service behind the front. To this the Basters agreed." negotiations, Seitz sent a written undertaking to the Baster Council on 21 August 1914 "dass die Bastardkompagnie eingezogen ist, um die Ruhe und Sicherheit im Lande (emphasis GJJO) aufrecht zu erhalten und Viehdiebe und andere Räuber zu fangen. Die Bastards werden nicht zum Kampfe gegen Weisse(n) verwendet werden". ${ }^{12}$

In the light of the assurance that they would not be used against whites and under the impression that they would only be used in the Rehoboth Gebiet, the Basters agreed to the reinstatement of the Baster Corps, ${ }^{13}$ which was established before the end of August 1914 with 176 men. ${ }^{14}$ The corps was under the command of German officers Captain Von Gaertringen, Lieutenant Von Kleist, Second Lieutenant Von Milkau and Second Lieutenant Von Könitz, as well as twelve non-commissioned officers. ${ }^{15}$ The whole Baster Corps was issued with German uniforms. The Basters could not see the necessity for this and were afraid that,

\footnotetext{
O. von Weber, Geschichte des Schutzgebietes Deutsch-Südwest-Afrika (Windhoek, 1974), p.219.

H. von Oelhafen, Der Feldzug in Südwest 1914/I5 (Berlin, 1923), p.144.

10 National Archives Windhoek (NAW) A312:14/15, Survey of international affairs, 1929, no. III, p.19.
}

" K.F.R. Budack, "Der 'Bastardaufstand' in Deutsch-Südwestafrika", Afrikanischer Heimatkalender, 1974, p. 43.

12 D. de Waal, Report on the inquiry in regard to the German-Bastard question held at Rehoboth and other places in the Military Protectorate in June, 1915 (Pretoria, 1915), p.32.

13 O. von Weber, Geschichte des Schutzgebietes ..., p.219.

14 D. de Waal, Report on the inquiry in regard to the German-Bastard question .... pp.9, 18-19; Die Suidwes-Afrikaner, 22.09.1970.

is H. Grimm, Das deutsche Südwester-Buch (München, 1937), p.376; H. von Oelhafen, Der Feldzug ..., p.145. 
dressed in German military uniforms, they would later be used as soldiers. The wearing of these uniforms consequently caused great dissatisfaction. ${ }^{16}$

After its establishment, the Baster Corps was soon transferred to Nauchas and subsequently in November to Kraaipoort, outside the Rehoboth Gebiet. The Basters regarded this action as a breach of faith. They were apparently under the impression that with "im lande" Seitz had only meant the Rehoboth Gebiet. ${ }^{17}$ This interpretation was, however, contradictory to the military treaty of 1895 . In paragraph nine, for example, the German government undertakes as far as possible to contribute to the care of the widows and children of the Basters who died in battle "ausserhalb des Rehobother Gebietes."18 As a matter of fact, under the terms of the 1895 treaty, the Basters in general participated enthusiastically in the suppression of different uprisings and did not raise any objection to being used outside the Rehoboth Gebiet. ${ }^{19}$

Samuel Beukes and Albert Mouton, as representatives of the Baster Council, consequently went to Kraaipoort to lodge an objection. Von Gaertringen and Dr. Kleist promised to submit their objections to the German government in Windhoek. The Baster soldiers were, however, shortly thereafter sent further westwards to Jakkalswater and a number of them still further away from the Rehoboth Gebiet to Ururas on the Walvis Bay border. Baster protest against this action fell on deaf ears. ${ }^{20}$ The use of Baster soldiers, outside the Rehoboth Gebiet, despite continual protest, resulted in growing tension in the Baster-German relations.

\section{THE PRISIONERS-OF-WAR CAMP AT UITDRAAI}

In February 1915 a number of German non-commissioned officers and Baster soldiers under the command of Lieutenant Hunoldt set up a prisoners-of-war camp at Uitdraai (situated on the railway line about 25

D. de Waal, Report on the inquiry in regard to the German-Bastard question ..., pp.18-19.

D. de Waal, Report on the inquiry in regard to the German-Bastard question ...., p.9.

18 NAW Quellen 22b, Auszug aus dem Bericht von Missionar F. Heidmann, 24.09.1895 (Rehoboth), p.427.

19 Cf. G.J.J. Oosthuizen, Die Rehoboth-Basters ..., pp.37-45, 47-49.

20 1. Goldblatt, History of South West Africa from the beginning of the nineteenth century (Cape Town, 1971), p.204; H. Grimm, Das deutsche Südwester-Buch, pp.378, 381; R. Henning, Deutsch-Südwest im Weltkriege (Berlin, 1920), p. 216. 
kilometres south-east of Rehoboth), intended for 120 South African prisoners-of-war captured during the combat at Sandfontein. The prisoners-of-war arrived about a week after their arrival. From the outset Captain Von Gaertringen protested against the use of 46 Baster guards who were bound to the South Africans by blood and language ties. They could, however, not be replaced because of a shortage of manpower. ${ }^{21}$

The Basters were greatly upset, because they regarded this order as being in direct contrast to the promise that they would not be used against the South African forces. The Baster guards raised their objections to the Baster Council, who in turn protested to the German government, without any success. ${ }^{22}$

The Basters assured the South African prisoners-of-war that they were under duress to act as guards and at the first and best opportunity they would lay down their arms. ${ }^{23}$ The Baster guards furthermore provided various prisoners intent on escaping with the necessary provisions. ${ }^{24}$ On the other hand, the South Africans were upset that they were being guarded by Coloureds and threatened that they would be prosecuted after victory by the South African forces. The Germans, thoroughly aware of the Basters' doubtful loyalty, forbade the prisonersof-war to talk to the Baster guards ${ }^{25}$ and limited the guards to three bullets each. $^{26}$

General Louis Botha, commander of the South African forces, had already in February 1915 communicated with Lieutenant Colonel Franke, successor to Von Heydebreck, ${ }^{27}$ regarding the use of armed non-whites. For example, a dead Baster soldier, dressed in German military uniform, was found after the attack on Keimoes. He was also aware of a large number of armed non-whites from the Cameroon ${ }^{28}$ who found themselves

\footnotetext{
21 H. von Oelhafen, Der Feldzug ..., p.146; D. de Waal, Report on the inquiry in regard to the German-Bastard question ..., pp.9, 18-19.

22 D. de Waal, Report on the inquiry in regard to the German-Bastard question ..., p.9.

23 P. Pearson, The history and social structure ..., p.157.

24 H. von Oelhafen, Der Feldzug ..., p. 146.

25 P. Pearson, The history and social structure ..., p. 157.

${ }_{27}$ H. von Oelhafen, Der Feldzug .... p. 146.

27 Oberstleutnant von Heydebreck died in November 1914 and was succeeded by Viktor Franke as commander of the German forces. Cf. G. Pool, Pionierspoorweè in Duits-Suidwes-Afrika 1897 1915 (Durban, 1982), p.256; H.E. Lenssen, Chronik von Deutsch-Südwestafrika. Eine kurz gefasste Aufzählung geschichtlicher Ereignisse aus der Deutschen Kolonialzeit von 1883-1915 (Windhoek, 1966), pp.219,229.

28 Cf. H.E. Lenssen, Chronik von Deutsch-Südwestafrika ..., p.235.
} 
at Omaruru. Botha undertook to disarm those armed non-whites in his service and that he would in future only use armed whites. He requested Franke to give the same assurance as soon as possible. ${ }^{29}$ Franke assured Botha that both the Cameroon and Baster companies were used solely for police service among the local non-whites. He unequivocally excused himself from using non-whites to fight against whites, and implied that in this connection Botha ought to be in the dock. ${ }^{30}$

\section{CAPTAIN CORNELIUS VAN WYK MEETS GENERAL LOUIS BOTHA}

While the mutual accusations between Franke and Botha regarding the use of non-whites were taking place, the increasing involvement of the Baster soldiers in the German war effort caused great concern within the Baster community. The Baster Council therefore decided that Captain Cornelius van Wyk should as soon as possible explain their position to the South African military authorities. ${ }^{31}$ In February or March 1915 Van Wyk obtained permission to visit the game reserve in the KuisebSwakopmund region, under the pretext that he wanted to look for bushtee and salt. Actually he travelled through the barren Namib rand region to establish contact with the South Africans. ${ }^{32}$ He was accompanied by Samuel Beukes and Dirk van Wyk. He was given a hearing by General Botha on 1 April. ${ }^{33}$

Unfortunately the conversation was not put in writing and consequently there are many obscurities regarding it. General Botha did, however, send a cable to General Smuts that he had had talks with Van Wyk and that the Baster leader was "well disposed" towards the Government. ${ }^{34}$ According to the Baster version, Van Wyk had handed a copy of the 1885 agreement to General Botha. After the general had read

\footnotetext{
PRO CO 551:72, Letter Franke/Botha, 28.02.1915, p.2.

PRO CO 551:72, Letter Franke/Botha, 11.03.1915, p.2.

D. de Waal, Report on the inquiry in regard to the German-Bastard question ..., pp.9,18.

H. von Oelhafen, Der Feldzug ..., p.146; R. Hennig, Deutsch-Südwest ..., p.217.

NAW Mem. 4/24, J.D. Viall, The History of the Rehoboth Basters, p.25; W.S. Rayner and W.W. O'Shaughnessy, How Botha and Smuts conquered German South West. A full record of the campaign from official information by Reuter's special war correspondents who accompanied the forces sent by the Government of the Union of South Africa (London, 1916), p.262.
} 
it, Van Wyk explained the situation in which his people found themselves. When asked whether he would respect the Basters' rights if he took the country, Botha, according to Baster tradition replied: "Al wat daardie traktaat vir julle gee, sal julle minstens hou" ${ }^{35}$ No documentary evidence exists to verify the validity of this undertaking.

During the interview Botha requested the Baster captain not to become involved in the war and emphasised that he would under no circumstances accept any military support from the Basters. ${ }^{36}$

Cornelius van Wyk's motivation to Botha that the Basters did not want to fight on the side of the Germans because they were British subjects by birth, ${ }^{37}$ has no justification. The Basters realised that if they did not unequivocally explain their efforts to the South Africans to remain neutral, they could possibly lose their territory and self-government. ${ }^{38}$

\section{PLANNED TRANSFER OF THE BASTER CORPS TO THE NORTH}

As a result of the military successes of the South African forces, it became urgently necessary to transfer the prisoners-of-war and the Baster Corps to the north of South West Africa. ${ }^{39}$ Von Gaertringen consequently informed the Baster Council on 13 April 1915 of the planned transfer to Otjiwarongo. The Baster Council refused to comply with this request. They were afraid that, if the Baster Corps were moved to the north, the South Africans would no longer recognise their neutrality. ${ }^{40}$

Von Gaertringen accordingly arranged a meeting between the Baster Council and Franke for the following morning at the Rehoboth station, approximately 12 kilometres from Rehoboth. Franke requested councillors Samuel Beukes, Pieter Mouton, Martinus Swart, Daniël Cloete and Carolus Swart to allow the Baster Corps to be moved

P.F. van der Schyff, Eric H. Louw in the Suid-Afrikaanse politiek tot 1948 (D.Litt., PU vir CHO, 1974), pp.70-72. According to Van der Schyff's research, Eric Louw acted as legal adviser to Van Wyk.

35 U.G. 41-1926, Rapport van die Rehoboth Kommissie, p.233; NAW Mem. 4/24, J.D. Viall, The History of the Rehoboth Basters, pp.25-26.

NAW SWAA A206/3 Rehoboth Baster Gebiet. Rehoboth affairs (annexure A), Letter C. van Wyk/T.L. Schreiner, 27.08.1917, p.1.

38 Allgemeine Zeitung, 21.09.1920.

39 O. von Weber, Geschichte des Schutzgebietes ..., p.219. 
northwards to guard prisoners. This they refused. Franke then granted them three days to decide between moving or laying down arms and remarked that the South Africans would hang any armed Baster they encountered from the nearest tree. According to Samuel Beukes, Franke remarked in German to Von Gaertringen after the meeting that if any of them should refuse, they would be shot in one heap. ${ }^{41} \quad$ It is, however, unlikely that Franke would ever have made such an irresponsible remark while the sensitive negotiations were going on. Whatever the factual truth, it is clear that Beukes had experienced such a threat, and this certainly decided his further actions.

Franke returned to Rehoboth station on 17 April to personally ascertain what the Basters' decision was. Von Gaertringen and his secretary, Widmann, accompanied councillors Mattheus Gertze, Albert Mouton and Carolus Swart to Rehoboth station. ${ }^{42}$ Gertze described the second meeting as follows: "When Franke saw us, he greeted us, and asked what our names were. He said that we should allow our soldiers to go to the north and that we should surrender our arms. We did not reply. He knew what our reply was. He said that he would give us five to six days to decide. Thereupon he entered his railway carriage and left by train." 43

Gertze, however, in his evidence kept back the fact that the councillors present had asked for a postponement to influence their compatriots more strongly against the Germans. ${ }^{44}$ His version of the German conduct indicates that he had experienced it as haughty and unyielding.

\section{BASTER SOLDIERS DESERT AT UITDRAAI}

While the negotiations regarding the transfer were held at high level, the Baster guards at Uitdraai notified the Baster Council on 17 April of their displeasure by threatening to desert. The Baster Council's decision

\footnotetext{
K.F.R. Budack, "Der 'Bastardaufstand' ...", p.47.

1 Cd 9146, Union of South Africa, Report on the natives of South West Africa and their treatment by Germany (Pretoria, 1918), p.128; H. von Oelhafen, Der Feldzug ..., p.147.

42 D. de Waal, Report on the inquiry in regard to the German-Bastard question ..., p.22; H. von Oelhafen, Der Feldzug ..., p.147; R. Henning, Deutsch-Südwest ..., p.219.

43 D. de Waal, Report on the inquiry in regard to the German-Bastard question ..., pp.10, 22.

44 H. von Oelhafen, Der Feldzug ..., p.147; O. von Weber, Geschichte des Schutzgebietes ..., p.220.
} 
reached them at about midnight. The Council urgently requested them to be patient, as they were still busy with negotiations. The Baster Council, was however, unaware that the train which would transport both the prisoners-of-war and the Baster guards to the north the following morning, had already arrived. ${ }^{45}$

During the night of 17 and 18 April the Baster guards deserted. About half of them were armed with German rifles, while the other half possessed their own weapons. According to Frederick Draghoender, one of the guards, they intended returning the German weapons to their headquarters in Rehoboth. They did not plan a rebellion against the Germans, but deserted in protest against their deployment against the South African forces and the decision to move them northwards. They reached Rehoboth, about 25 kilometres from Uitdraai, the following morning at about twelve o'clock. ${ }^{46}$ By the afternoon of 18 April about three hundred armed Baster men ${ }^{47}$ had entrenched themselves in two laagers, under the command of Dirk van Wyk and Samuel Beukes, immediately to the south and west of Rehoboth. ${ }^{48}$

Lieutenant Hunoldt telegraphed the events to Rehoboth, and the Captain Müller, immediately requested Windhoek to send reinforcements. The first reinforcements under Lieutenant Bach arrived at Rehoboth station that same day. ${ }^{49}$

\section{ATTEMPTS AT DISARMAMENT}

During the early morning hours of 18 April it was decided to disarm the remaining Baster soldiers at Rehoboth, Sandputs, Vaalkrans and Kraaipoort. Two guards, Klaas van Wyk and Jacob Morkel, who had to tend to government horses at Rehoboth, were disarmed and arrested by Police Sergeant-major Buertner and five men. Morkel, however, escaped shortly afterwards, and a shot was fired at him. This caused great alarm and some Basters fled in the direction of the mountains. ${ }^{50}$ The

\footnotetext{
D. de Waal, Report on the inquiry in regard to the German-Bastard question ..., pp.10, 28.

R.G. Britz, L. de Vries en A. Olivier, Ons Eeufees 1870-1970 (Rehoboth, 1970), pp.48-49.

R. Henning, Deutsch-Südwest ..., p.219; H. von Oelhafen, Der Feldzug ..., p.148.

D. de Waal, Report on the inquiry in regard to the German-Bastard question ..., pp.11, 29.

49 R. Henning, Deutsch-Südwest ..., p.219; H. von Oelhafen, Der Feldzug ..., p.148; NAW A566:1,

Der Feldzug in Deutsch-Südwestafrika 1914/15, p.88.

D. de Waal, Report on the inquiry in regard to the German-Bastard question ..., pp.20, 26.
} 
disarmament of the Basters at Vaalgras and Kraaipoort proceeded without any incident. ${ }^{51}$

At Sandputs, about 12 kilometres west of Rehoboth, eight Germans and nine Baster soldiers were under the command of Dr. Bauer, a veterinarian. The Baster soldiers were disarmed at about three o'clock on the morning of 18 April, whereupon the Germans went to the house of another Baster soldier, a certain Coetzee, to disarm him also. Shots that were fired at the fleeing Coetzee upset five of the prisoners to such an extent that they attempted to escape. Petrus Beukes was killed in the ensuing shooting. News of the incident spread like a wildfire throughout the whole Rehoboth Gebiet. Women and children fled in the direction of Sam Kubis. ${ }^{52}$

These attempts at disarmament and the death of the unarmed Petrus Beukes brought the tension to a breaking point. In an attempt to defuse the tense situation, further Baster-German negotiations were started.

The Baster leaders Matthews Gertze, Klaas Draghoender, a certain Klaasen, Carolus Swart and Willem Koopman, left for Windhoek on 18 April to consult the Governor. Governor Seitz saw them at nine o'clock on 19 April. Apart from Seitz and the Baster leaders, Lieutenant Colonel Bethe, Franke, Von Gaertringen and the missionary, Adolf Blecher of Rehoboth, were also present. The latter acted as interpreter. Seitz blamed the state of affairs on the laxity of the Baster Council, whereupon they in defence argued that they had kept Von Gaertringen informed from the outset. Seitz pointed out to the Basters that Germany was in a favourable position and that the South Africans would soon have to leave German South West Africa. The Basters would then have to account for their foolish behaviour. Seitz ordered the Basters to hand over all the government rifles and sent Bethe as delegate to proceed with the negotiations in Rehoboth. ${ }^{53}$

Bethe with the Baster leaders left for Rehoboth that same day where they arrived that evening. Shortly after their arrival Bethe sent Klaas Draghoender to the laagers of Samuel Beukes and Dirk van Wyk with the request that the councillors had to meet him. Only Pieter Beukes and

\footnotetext{
51 H. Grimm, Das deutsche Südwester-Buch, pp.383-384.

52 D. de Waal, Report on the inquiry in regard to the German-Bastard question .... pp.11, 29; R. Henning, Deutsch-Südwest ..., p.220.

53 R.G. Britz et al., Ons Eeufees ..., p.42.
} 
Albert Mouton responded to this request. Bethe then gave orders that issued government weapons were to be handed over to him, but emphasised that the Basters could keep their own weapons. ${ }^{54}$

Only eighteen old and useless weapons were handed in up to and including 21 April. Bethe returned to Windhoek that day to report to the Governor. On his return to Rehoboth on 22 April, he attempted to resume negotiations. However, that same day, Bethe finally abandoned the negotiations, which he described as viewless. ${ }^{55}$

It was not merely the refusal to hand in government weapons that had made Bethe abandon further negotiations. The fact that German citizens had been murdered by Basters, confronted the German government with a new situation.

\section{BASTERS MURDER GERMAN CITIZENS}

While the preceding desertion and joining of Baster forces were taking place, the Basters in turn tried to disarm the Germans in the Rehoboth Gebiet. Pieter Mouton, one of the Baster leaders, went to Schlip River, after the Basters had formed a laager, to call up his people to leave for the mountain fortress Sam Kubis. The purpose was to protect their wives and children against further German attacks. After learning that the police sergeant Siegmann was at the Schlip River police station, he and six men departed to disarm him. In the process Siegmann was wounded and Pieter Mouton allowed him, another German and his wife, to leave for Gras by wagon. The Basters took away five military rifles and two revolvers. ${ }^{56}$

Meanwhile, Cornelius van Wyk had returned from his visit to General Botha to his farm Garies about 86 kilometres south west of Rehoboth. Shortly thereafter, probably on 19 April, he, despite Botha's advice, ordered Niklaas and Willem van Wyk to disarm Police Sergeantmajor Rudolf Rogge at Bulspoort. According to Niklaas van Wyk's testimony, Rogge resisted and was shot fatally. Niklaas van Wyk sent two Nama policemen, Fritz and Karab, from Bulspoort to Ababis to disarm

\footnotetext{
54 D. de Waal, Report on the inquiry in regard to the German-Bastard question ..., p.22.

55 H. von Oelfhafen, Der Feldzug ..., p.148.

56 D. de Waal, Report on the inquiry in regard to the German-Bastard question ..., p.27; K.F.R. Budack, "Der 'Bastardaufstand'...", p.52.
} 
Adam Heine, a German farmer. ${ }^{57}$ On their way to Ababis they murdered the German farmer Richard Putzier at Zais on 20 April. ${ }^{58}$ The murderers arrived at Abibis on the morning of 21 April at six o'clock and also murdered Heine. According to the testimony of Heine's wife Anna, four armed Basters had meanwhile also arrived. They told her that the murders of Putzier, Rogge and Heine had taken place at the order of Captain Van Wyk and that they were on their way to Noab to kill Plugge, a farmer, also. The Basters stole all the livestock and ordered her to go to Garies. ${ }^{59}$ In the following days Sergeant Otto Schubert and Max Hefner of Swartfontein, Georg Eberhardt of Weissenfels, Hermann Hörmann of Derm-Wes and Karl Bauer and his family of Blumfelde were also murdered. ${ }^{60}$ These senseless murders forced the German authorities to take practical steps to protect their subjects against the Baster violence.

\section{GERMAN DECLARATION OF WAR AND SUBSEQUENT BATTLES}

On 22 April 1915 Lieutenant Colonel Bethe informed the Baster Council in writing that they had broken the Protection and Friendship Treaty of 15 September 1885 and that their conduct was regarded as a deed of open hostility: "The Imperial German Government is thereby forced, for the preservation of its rights, for the upkeep of peace and safety in the Protectorate, and for the protection of the life and property of subjects of the German Empire in German South West Africa, and of all other persons under its protection, to take such measures as it may deem necessary, for the serious consequences of which the Bastard community of Rehoboth will be answerable."61

57 D. de Waal, Report on the inquiry in regard to the German-Bastard question ..., pp.12, 30; H. Grimm, Das deutsche Südwester-Buch, p.384.

58 NAW ADM 37:323/6, Letter Officer i/c C.I.D. and Town Police/Officer commanding Military Constabulary, C.I.D. and Town Police, 18.02.1916, p.2.

59 R.G. Britz et al., Ons Eeufees ..., p.33; Südwest (Extrablatt), 25.04.1915,

60 Allgemeine Zeitung, 21.09.1920; H. Grimm, Das deutsche Südwester-Buch, p. 380; H.E. Lenssen, Chronik von Deutsch-Südwestafrika .... p.242; Südwest, 29.04.1915; Der Südwestbote, 6.05.1915; NAW A566:2, Briefe des Oberleutnants Arthur Schmitt der 7. (Kamelreiter-) Kompanie an seine Eltern, p.39.

61 NAW SWAA 2/18/2 Unregistered correspondence and papers, Rehoboth Affairs. Copies of correspondence and legislation, 1872-1922, Letter Lieutenant-Colonel Bethe/Council of the Bastards of Rehoboth, 22.04.1915; U.G. 41-1926, Rapport van die Rehoboth Kommissie, p.206. 
That same day Cornelius van Wyk appealed to General Botha to send reinforcements to Rehoboth. Botha, was however, determined that the Basters should not be involved in the war further and reacted as follows to van Wyk's request: "I would like to repeat to you again with the greatest earnestness that you must not proceed with this war; rather retreat some distance with your cattle and your people."

Botha urgently requested him to contact the South African forces who were on their way from Berseba to Gibeon, and to move his people and possessions to behind the South African lines. ${ }^{62}$

Brigadier General MacKenzie of the South African forces was requested to contact Van Wyk and his people from Gibeon and to move him and his people southwards. Before the message reached MacKenzie, he received news of the Baster rebellion from the German magistrate of Maltahöhe, who asked for protection against the Basters. ${ }^{63}$ Botha was aware that the Germans intended moving northwards and to leave women and children behind in Windhoek. If the Baster rebellion should spread further, the Germans would be forced to leave behind an adequate force to protect the women and children. This could affect the war situation considerably. ${ }^{64}$

On the same day that war was declared, Germany started their retaliatory attacks. A German division under Lieutenant Hugo Bach attacked the Basters, who were about three hundred men strong, at Rehoboth. The Basters were driven back in the direction of Heuras (also called Neuras), but because the Germans were not mounted, they could not follow up their success. ${ }^{65}$

A company under the command of Captain Remanofsky attacked a Baster convoy consisting of six wagons and a Cape cart (hooded cart) on 23 April $^{66}$ at Heuras. The convoy was on its way to Sam Kubis. During the fight Frederik Keikop and the eighteen year-old daughter of Christian Vrij were killed, while Jan Witbooi and Willem Keikop were wounded.

62 SANDF DC 1129:1558/9199, Letter Botha/Van Wyk, 28.04.1915; R. First, South West Africa (Middlesex, 1963), p.90.

63 PRO CO 551:72, Daily Bulletin no. 206, 3.05.1915; Telegram Governor-General of the Union of South Africa/Secretary of State for the Colonies, 4.05.1915.

64 PRO CO 551:72, Telegram Governor-General/Secretary of State for the Colonies, 4.05.1915.

65 K.F.R. Budack, "Der 'Bastardaufstand' '..., " p.55.

(6) According to the De Waal report (cf. p.12) the battle had already taken place on 22 April 1915 , H.E. Lenssen (p.241) as well as H. von Oelhafen (p.148) indicate 23 April as the correct date. 
The Germans burnt all the wagons and shot all the livestock. The Basters who were able to escape, arrived at Sam Kubis a few days later. ${ }^{67}$

A German division under the command of Captain Seydel, which was on its way from Mariental by rail to Rehoboth, attacked a large Baster convoy at Uitdraai, a small station, on 23 April. This convoy, which was on its way from Bloemputz to Sam Kubis, consisted of 32 armed and some unarmed Basters, 42 ox-wagons, eight Cape carts, more than fifty families and a large number of large and small livestock. The Basters were crossing the railway line from east to west when the Germans encountered them. The fight lasted for about two hours. Most of the Basters, succeeded in escaping with their wagons however. ${ }^{68}$ The Germans burnt a dozen wagons and captured eight hundred head of large cattle and a few thousand small stock. ${ }^{69}$

After the attack on Heuras the Fifth Reserve Company withdrew to Rehoboth. During the march back they met the convoy that had escaped during the attack at Uitdraai at Kabirab on the night of 23/24 April. After a short gun-fight the Basters fled among great confusion to the mountains. The Germans burnt the ox-wagons and Cape carts that were partially loaded with weapons and ammunition and shot the trek oxen and livestock. $^{70}$

On 24 April 1915, Captain Count Von Saurma-Jeltsch was appointed commander in the subsequent campaign against the Basters. The next day he started his advance from Rehoboth to Sam Kubis where the Basters were preparing to beat off a final German attack. ${ }^{71}$ During the German advance, the Basters lay in ambush at a river near Konub and in the subsequence skirmish Sergeant-Major Siegeler, Lance-Corporal Kuhr and Second Lieutenant Von Milkan were killed in action. The latter, who was seriously wounded, was cold-bloodedly murdered by Jakobus Beukes, a former Baster soldier. ${ }^{72}$

\footnotetext{
67 D. de Waal, Report on the inquiry in regard to the German-Bastard question ..., pp.12-13, 22-23; Südwest (Extrablatt), 25.04.1915; Der Südwestbote, 26.04.1915.

68 R.G. Britz et al., Ons Eeufees .... p.35; H.E. Lenssen, Chronik von Deutsch-Südwestafrika .... p.241; H. von Oelhafen, Der Feldzug ..., p.148.

69 H.E. Lenssen, Chronik von Südwestafrika ..., p.241; H. von Oelhafen, Der Feldzug..., p. 148.

70 D. de Waal, Report on the inquiry in regard to the German-Bastard question ..., pp.13,24,

7 H. von Oelhagen, Der Feldzug ..., p.150; H.E. Lenssen, Chronik von Südwestrafrika.., p. 242.

72 H. von Oelhafen, Der Feldzug ..., p.150; R. Hennig, Deutsch-Südwest ..., p.223; H. Grimm, Das deutsche Südwester-Buch, p.389; Südwest (Extrablatt), 8.05.1915; NAW, A566:2, Briefe des Oberleutnants Artur Schmitt der 7. (Kamelreiter-) Kompanie an seine Eltern, p.47.
} 
A German division under the command of Captain Hensel strengthened the ranks of Von Saurma-Jeltsch at Klein Aub on 3 May. The following day they engaged in fighting with a group of Basters who were hiding in the mountains at Garies. Eighteen Basters died during this battle. $^{73}$

As a precautionary measure, Captain Cornelius van Wyk hid his wife and their five children, as well as the wives and children of Stoffel and Willem van Wyk, on a mountain near his farm Garies. On 4 May a German patrol under Lieutenant Von Woikowsky ${ }^{74}$ discovered them. Two children and Stoffel van Wyk's wife, as well as an adult daughter of the captain, who tried to escape, were fatally shot. According to the captain's wife Sara, their eighteen year-old son Hermanus was afterwards taken away from the group and executed. The German soldiers took the rest of the group to the Leutwein station where they were released on 13 May. $^{75}$

\section{THE BATTLE OF SAM KUBIS, 8 MAY 1915}

Sam Kubis, situated about 50 kilometres south west of Rehoboth, is a natural, almost impregnable, mountain stronghold - a circle of mountains with a single entrance a few hundred metres wide. At the outbreak of hostilities the Basters fled post-haste to it. ${ }^{76}$

Early in May 1915 between seven and eight hundred Basters were entrenched at Sam Kubis. ${ }^{77}$ The Germans, who used two cannons and three Maxim machine-guns, ${ }^{78}$ proceeded to attack at six o'clock of the morning of 8 May. The Fourth Reserve Company attacked from the east and south, and the Fifth Reserve Company from the opposite side. ${ }^{79}$

73 H. von Oelhafen, Der Feldzug ..., pp.151-152; NAW A566:1, Der Feldzug in DeutschSüdwestafrika 19/4/15, p.89.

74 H. von Oelhafen, Der Feldzug ..., p.152.

75 NAW ADM 137:C16, Statement by C. van Wyk, 17.09.1915; Report Lieutenant T. Swanson/Adjutant 3rd S.A.M.R., 26.09.1915; D. de Waal, Report on the inquiry in regard to the German-Bastard question ..., pp.14,18,24-25.

76 D. de Waal, Report on the inquiry in regard to the German-Bastard question ..., p. 12.

77 H. von Oelhafen, Der Feldzug ..., p.153; NAW A566:1, Der Feldzug in Deutsch-Südwestafrika $1914 / 15$, p. 89.

78 SANDF DC 1129:1558/9199, Statement by chief Van Wyk and Bastard Raad, Rehoboth, 10.05.1916, pp.2-3; CD 9146, Union of South Africa, Report on the natives of South West Africa ..., p. 130 .

79 H. von Oelhafen, Der Feldzug .... p.153; NAW A566:1, Der Feldzug in Deutsch-Südwestafrika $1914 / 15$, p.90. 
The Basters defended themselves bravely, but their ammunition was insufficient. To the great relief of the Basters, the Germans ceased their attack at sunset. The next morning a German patrol under Second Lieutenant L. Stark arrived with the news that the military post at Nauchas had to be evacuated because of the South African advance. Shortly afterwards Captain Count von Saurma-Jeltsch also received the order to withdraw to Rehoboth. The German side only lost three noncommissioned officers and two soldiers, while nine men were wounded. ${ }^{80}$ The Basters suffered great losses: in one of the captured trenches the Germans found seventeen Basters who had died in battle. ${ }^{81}$

For the Basters at Sam Kubis the arrival of the South African forces under the command of Brigadier-general MacKenzie, in the Rehoboth Gebiet, was very timely, because it forced the Germans to withdraw, preventing the Basters from being wiped out totallyat Sam Kubis. ${ }^{82}$ The Basters interpreted the sudden withdrawal of the Germans, just as they were about to deliver the final blow, as a direct intervention by God. Sam Kubis Day is still celebrated annually with great enthusiasm and was proclaimed a public holiday by the Baster Council. ${ }^{83}$ During these meetings the so-called Covenant of Sam Kubis, ${ }^{84}$ which strongly resembles the Covenant of Blood River, was made by the celebrators.

After the battle of Sam Kubis the Basters cautiously started to return to Rehoboth. Subsequently Dirk van Wyk, one of the Baster leaders, ordered various people, including some Namas, to murder all Germans they found. A direct result of this was the murders of the farmers Eduard Wenzel at Achaubmund and Karl Herrmann at Rothenstein. ${ }^{85}$

Some German soldiers were placed on the farms Oamites, Haigamas, Gochaganas and Aris to protect the white population. At Klein-Nauas station nineteen men were deployed under the command of Second Lieutenant Aschenborn. They were supported by 22 armed

80 R. Henning, Deutsch-Südwest ..., pp.224-225; H. von Oelhafen, Der Feldzug ..., pp.153-154; Cape Times, 6.04.1925.

81 H. von Oelhafen, Der Feldzug .... p.154.

82 U.G. 41-1926, Rapport van die Rehoboth Kommissie, p.44; O. von Weber, Geschichte des Schutzgebietes..., p.220.

83 R.G. Britz et al., Ons Eeufees ..., p.24; Die Suidwester, 5.05.1981.

${ }^{84}$ Research could not determine when and by whom the vow was made. It probably came about after the battle of Sam Kubis. Cf. F.J. Strydom, Die musiek van die Rehoboth Basters (D.Phil., Universiteit van Stellenbosch, 1983) pp.79-80. 
civilians and had to serve as a buffer against the Basters. With the arrival of the South Africans from the south, these posts were also vacated on 23 May. ${ }^{86}$ The homes and farms of the German inhabitants of Rehoboth and the farmers of the Rehoboth Gebiet who went to Windhoek under orders of the German authorities, were plundered by the returning Basters who also stole their livestock. ${ }^{87}$ Even the houses of the Rehoboth missionaries Blecher and Schröer suffered. ${ }^{88}$

The extensive bloodshed, destruction and theft of property by both Basters and Germans plunged the Rehoboth Gebiet in total chaos, caused nameless misery and precipitated protracted feelings of resentment.

\section{WHO WAS TO BLAME?}

General Botha, who occupied Windhoek on 12 May 1915 without striking a blow, ${ }^{89}$ was eager that the situation in the Rehoboth Gebiet should be normalised as soon as possible. Colonel H Mentz was consequently sent to Rehoboth where he held discussions with Pieter Mouton, one of the Baster Council members, and other Baster leaders. He requested the Basters to return to their homes and assured them that they had nothing to fear from the Germans, because the South Africans were in control at Windhoek from where they would send regular patrols to the south. The Basters could go and look for their lost livestock, but had to obtain the necessary letters of authority from the Baster Council. He urgently requested them to avoid any further confrontation with the Germans. If a Baster should find any of his livestock on a German's farm, he had to report it immediately to Windhoek, whereupon a patrol would be sent to investigate. Mentz also promised that a board or commission of investigation would in due course be sent to Rehoboth to resolve the Baster-German issue. ${ }^{90}$

\footnotetext{
85 NAW LRE 1/1/1. Criminal cases, Rex versus Willem, alias Harip and eleven others, A1-A3, A 16; Allgemeine Zeitung, 21.09.1920.

86 O. von Weber, Geschichte des Schutzgebietes..., p.221; NAW A566:2, Briefe des Oberleutnants Artur Schmitt der 7. (Kamelreiter-) Kompanie an seine Eltern, p.40. Allgemeine Zeitung, 21.09.1920. K.F.R. Budack, "Der 'Bastardaufstand' ...", p.61.

The Times, 10.07.1915; H.E. Lenssen, Chronik von Südwestafrika ..., p.243.

NAW LRE 3/1/1:66/16, Letter Colonel H. Mentz/Captain C. van Wyk, 24.05.1915.
} 
As promised, Lieutenant-Colonel D. de Waal visited the Rehoboth Gebiet in June 1915 to investigate the reasons for the Baster rebellion. ${ }^{91}$ In his report, which was completed July 1915, he blamed the Germans for the Baster rebellion: "To whom is to be ascribed the cause of all this? ... Who is responsible for this reckless slaughter and destruction? To my mind there is but one answer to these questions ... The Bastards are a peaceful race and they strike me as a people who would in no [way] abandon themselves to acts of violence ..."92

De Waal's analysis of the events are, however, strongly suspect. His report is without doubt the product of a period when acute negative feelings were borne against the Germans. For example, the majority of evidence on which his report is based, came from Basters. In fact, only a few testimonies by Germans were included in hisport. The Military Treaty of 1895 , on which he could base the Baster's military duties, did not play a role in the report at all.

The Basters' fear that they could lose their territory and right to selfgovernment if they actively support the Germans, could be regarded as the main reason for the rebellion. The Basters had once again, as previously during the Herero-Nama-Oorlam clashes and subsequently when the Germans, succeeded in choosing the winning side.

\section{$---000 \mathrm{Oooo---}$}

The German forces in the north were surrounded by the South Africans and were forced to surrender. ${ }^{93}$ The peace negotiations took place from 4 to 9 July $1915 .^{94}$ On 9 July 1915 the German civil administration in South West Africa was formally ended, after Governor Seitz and Lieutenant Colonel Franke had signed General Botha's reasonable peace conditions at Kilo 500 on the railway line between Otavi and Khorab. ${ }^{95}$ After the Peace of Khorab, the South African Government formally took

\footnotetext{
91 D. de Waal, Report on the inquiry in regard to the German-Bastard question ..., p.6.

92 D. de Waal, Report on the inquiry in regard to the German-Bastard question ..., pp.14-15.

93 SANDF DC 728:DB 1432/9199, Minute 850, 9.07.1915; The Times, 12.07.1915.

94 T. Seitz, Südafrika im Weltkriege. Der Zusammenbruch in Deutsch-Südwestafrika. Die Politik der Südafrikanischen Union während des grossen Krieges (Berlin, 1920), p.48.

95 PRO CO 551:74, Telegram Governor-general of the Union of South Africa/Secretary of State for the Colonies, 10.07.1915; SANDF DC 728:DB1432/9199 (sublêer DB 24/1432/Z), Minute 850, 9.07.1915; The Times, 12.07.1915; NAW A566:2, Briefe des Oberleutnants Artur Schmitt der 7. (Kamelreiter-) Kompanie an seine Elten, pp.63-66.
} 
Scientia Militaria, South African Journal of Military Studies, Vol 28, Nr 1, 1998. http://scientiamilitaria.journals.ac.za

over the administration of South West Africa and placed the territory under martial law. ${ }^{96}$

96 Official Gazette of the Protectorate of South West Africa, 13.08.1915, pp.1-2. 